\title{
Prospective Spatial-Temporal Clusters of COVID-19 in Local Communities: Case Study of Kansas City, Missouri, United States
}

\author{
Hadeel Alqadi ${ }^{1,2, *}$, hadz6@ mail.umkc.edu \\ Majid Bani Yaghoub ${ }^{1}$, baniyaghoubm@umkc.edu \\ Siqi Wu ${ }^{1}$, sw4fc@mail.umkc.edu \\ Sindhu Balakumar', sbmbg@mail.umkc.edu \\ Alex Francisco ${ }^{3}$, Alex.Francisco@kcmo.org \\ ${ }^{1}$ Department of Mathematics and Statistics \\ University of Missouri-Kansas City \\ Kansas City, Missouri 64110-2499, USA \\ ${ }^{2}$ Department of Mathematics, Jazan University, Saudi Arabia \\ ${ }^{3}$ City of Kansas City, Missouri Health Department \\ 2400 Troost Ave Kansas City, MO 64108
}

\begin{abstract}
COVID-19 is an infectious disease caused by the severe acute respiratory syndrome novel coronavirus (SARS-CoV-2). Just in the United States (U.S.), the COVID-19 cases reached over 37 million, with more than 628,000 deaths as of August 2021. Kansas City in Missouri State has become one of the major U.S. hot spots for COVID-19 due to an increase in the rate of positive COVID-19 test results. Despite the large numbers of COVID-positive cases in Kansas City, the spatio-temporal analysis of data has been less investigated. However, it is critical to detect emerging clusters of COVID-19 and enforce control and preventive policies within those clusters. In this study, we conducted a prospective Poisson spatial-temporal analysis of Kansas City, MO, COVID-19 data at the zip code level. The analysis focused on daily COVID-19 cases in four equal periods of three months. We detected temporal patterns of emerging and reemerging space-time clusters between March 2020 and February 2021. In the first period, three statistically significant clusters emerged, which were mainly concentrated in downtown. In the second period, it increased to seven clusters, spreading across a wider region in downtown and north of Kansas City. In the third period, there were nine clusters covering large areas of north and downtown Kansas City, MO. In the last period, 10 clusters were present and further extended the infection along the state line. The statistical results were communicated with local health officials and provided the necessary guidance for decision making and the allocation of resources (e.g., vaccines and testing sites). As more data become available, statistical clustering can be used as a COVID-19 surveillance tool.
\end{abstract}

Keywords: Covid-19, Pandemic, Periodic surveillance, Cluster analysis, Spatial, Disease, Spacetime clusters, SatScan 


\section{Introduction}

COVID-19 is an infectious disease caused by SARS-CoV-2, a beta coronavirus with crown-like spikes (Centers of Disease Control and Prevention, 2021a). COVID-19 is transmitted by close human contact, and respiratory droplets can cause infection upon entering the body (Centers of Disease Control and Prevention, 2021b) .

While coronaviruses are commonly found in a variety of animal species, SARS-CoV-2 is a severe acute respiratory syndrome coronavirus that typically causes mild upper respiratory tract illnesses (Centers of Disease Control and Prevention [CDC], 2021c). The most common symptoms of COVID-19 include fever, dry cough, and tiredness. Serious symptoms, such as difficulty breathing or shortness of breath, chest pain or pressure, and loss of speech or movement, may appear 2-14 days after exposure to the virus (CDC, 2021d; Shi et al., 2020). The United States (U.S.) has experienced over 37 million COVID-19 cases and more than 628,000 deaths as of August 2021 (CDC, 2021e).

COVID-19 originated from a seafood market in Wuhan, China in December 2019. However, the World Health Organization (WHO, 2020a) declared this outbreak a pandemic in March 2020. This devastating outbreak impacted the U.S. in terms of mortality and economy. Stricter lockdown measures were enforced to combat rising COVID-19 cases, resulting in a global economic crisis. Therefore, a whole society is facing several challenges, including food security, public health, and employment and labor issues (WHO, 2020b). For instance, in June 2021, cereal prices were 43\% higher than in January 2020. High food prices reflect supply disruptions due to COVID-19 social distancing measures, currency devaluations, and other factors (The World Bank, 2021). In the face of the COVID-19 pandemic, shortages of physicians and other healthcare providers have brought more challenges to rural communities (Melvin et al., 2020). The COVID-19 pandemic has also created job losses, with 22 million jobs lost between February and April 2020 (Groshen, 2020).

On December 13, 2020, the first COVID-19 vaccinations were administered (CDC, 2021f). Currently, three vaccines have been authorized by the FDA: Pfizer-BioNTech, Moderna, and Johnson \& Johnson. Pfizer and Moderna are both mRNA vaccines that deliver the genetic code from SARS-CoV-2 to cells in the host's body, producing copies of spike proteins that result in an immune response that creates antibodies (Yale Medicine, 2021a). By contrast, Johnson \& Johnson is a carrier vaccine that orders the host to make SARS CoV-2 spike proteins, resulting in antibody production to prevent future infection (Yale Medicine, 2021a). Overall, Pfizer is 95\% effective, Moderna is $94.1 \%$ effective, and Johnson \& Johnson is $72 \%$ effective in preventing COVID-19 (Yale Medicine, 2021a).

Nevertheless, COVID-19 continues to spread globally, and variants of the virus are rapidly emerging. There are currently four variants identified in the U.S.: Alpha, Beta, Gamma, and Delta. The Delta variant was first identified in the U.S. in March 2021 and is highly transmissible and more contagious than the original strain, posing a serious threat to unvaccinated individuals (CDC, 2021g). Fully vaccinated individuals have protection against this variant, so those who are unvaccinated are at a higher risk for infection and hospitalization (Yale Medicine, 2021b). In fact, $97 \%$ of patients who are hospitalized with COVID-19 in the U.S. are unvaccinated (UC Davis Health, 2021). 
Despite the efficacy of these vaccines, many individuals still have concerns about getting vaccinated. For instance, Missouri's vaccination efforts currently rank $43^{\text {rd }}$ in the country, and only $39 \%$ of Missourians are reportedly fully vaccinated. As of July 2021, over 5,236,000 total vaccine doses had been administered in Missouri (Missouri's COVID-19 Dashboard, 2021). Of particular interest, Kansas City, MO, reports that only $37.5 \%$ of its population is fully vaccinated (Kansas City COVID-19 Information Center, 2021).

In fact, Kansas City, MO, has become a major U.S. hot spot for COVID-19 due to an increase in the rate of positive COVID-19 test results. To combat the threat, Kansas City's mayor, Quinton Lucas, issued a State of Emergency proclamation on March 12, 2020, which mandated masks and restricted gatherings and congregations of individuals (Kansas City Health Department, 2021a). Kansas City also encourages individuals to stay at least six feet away from others, avoid crowds and poorly ventilated spaces, and maintain proper hygiene by washing hands thoroughly. Despite efforts to contain the virus, Kansas City, MO, has observed 79,000 confirmed cases and 897 deaths as of August 2021 (Kansas City Health Department, 2021b).

During an emerging pandemic with different strains, such as COVID-19, it is critical to implement space-time surveillance that can identify clusters of the hardest-hit areas. Cluster detection of when and where transmission of COVID-19 occurs is crucial to reduce the chances of another wave, to avoid the rise of small local outbreaks, and ultimately to control the epidemic. In addition, spatial-temporal analysis will lead to implementing more control measures and establishing testing and vaccination sites in the most affected areas.

Among the global measures of spatial-temporal clustering analysis, space-time scan statistics are one of the most popular and powerful techniques applied to perform geographical surveillance of disease and to evaluate repeated time-periodic disease surveillance for the early detection of spatial or space-time disease clusters to determine whether they are statistically significant (Kulldorff, 1997; Kulldorff and Nagarwalla, 1995). Spatial-temporal scan statistics have been implemented to perform surveillance of breast cancer in the northeast U.S. (Kulldorff et al., 1997), to detect malaria and guide malaria control programs in Mpumalanga Province, South Africa (Coleman et al., 2009), to detect the spatiotemporal variation of childhood diarrhea in northwest Ethiopia (Azage et al., 2015), and to provide surveillance of hemorrhagic disease (HD) in white-tailed deer in the southeastern U.S. (Xu et al., 2012).

To periodically monitor outbreaks, the prospective space-time scan statistic is used to detect active or emerging clusters of the disease, which can be used for surveillance during an ongoing epidemic (Kulldorff, 2001; Takahashi et al., 2008). The statistics will detect significant clusters that are active at the end of the study period. As more confirmed cases are updated, the prospective statistics track the active clusters in space and time, update relative risks (RRs) for each location affected by a disease, and detect emerging clusters. Prospective space-time scan statistics have been used for detecting male thyroid cancer in New Mexico (Kulldorff, 2001), terrorism outbreaks (Gao et al., 2013), Legionnaires' disease (Edens et al., 2019), and COVID19 clusters in the U.S. (Desjardins et al., 2020). 
Despite the high number of COVID-19 positive cases in Kansas City, statistical analysis of the spatiotemporal data has been absent until now. According to the WHO database, as of August 2021, only 45 and 24 of the 231,893 papers published concerning COVID-19 were relevant to Missouri and Kansas City, respectively. Therefore, it is critical to detect spatial clusters of COVID-19 in Kansas City, MO to implement more control measures as the outbreaks grow because of increased transmissibility due to the Delta variant.

Thus, our objective in this study is to detect significant space-time clusters of confirmed cases of COVID-19 at the zip code level in Kansas City, MO. The analysis focused on daily COVID-19 cases in four equal periods of three months between March 2020 and February 2021. The spacetime prospective statistic is useful because it detects active and emerging significant clusters of COVID-19 during the four periods, which can be informative for the decision makers to track cluster characteristics through time (cluster size, RR, observed, and expected cases). As more data become available, spatial clustering can be used as a COVID-19 surveillance tool.

\section{Materials and Methods}

\subsection{Study Area and COVID-19 Data}

The study area in this research is located in Kansas City, the western part of the U.S. state of Missouri. The space-time analysis was conducted in the four Kansas City counties: Jackson County, Platte County, Clay County, and Cass County (see Figure. 1).

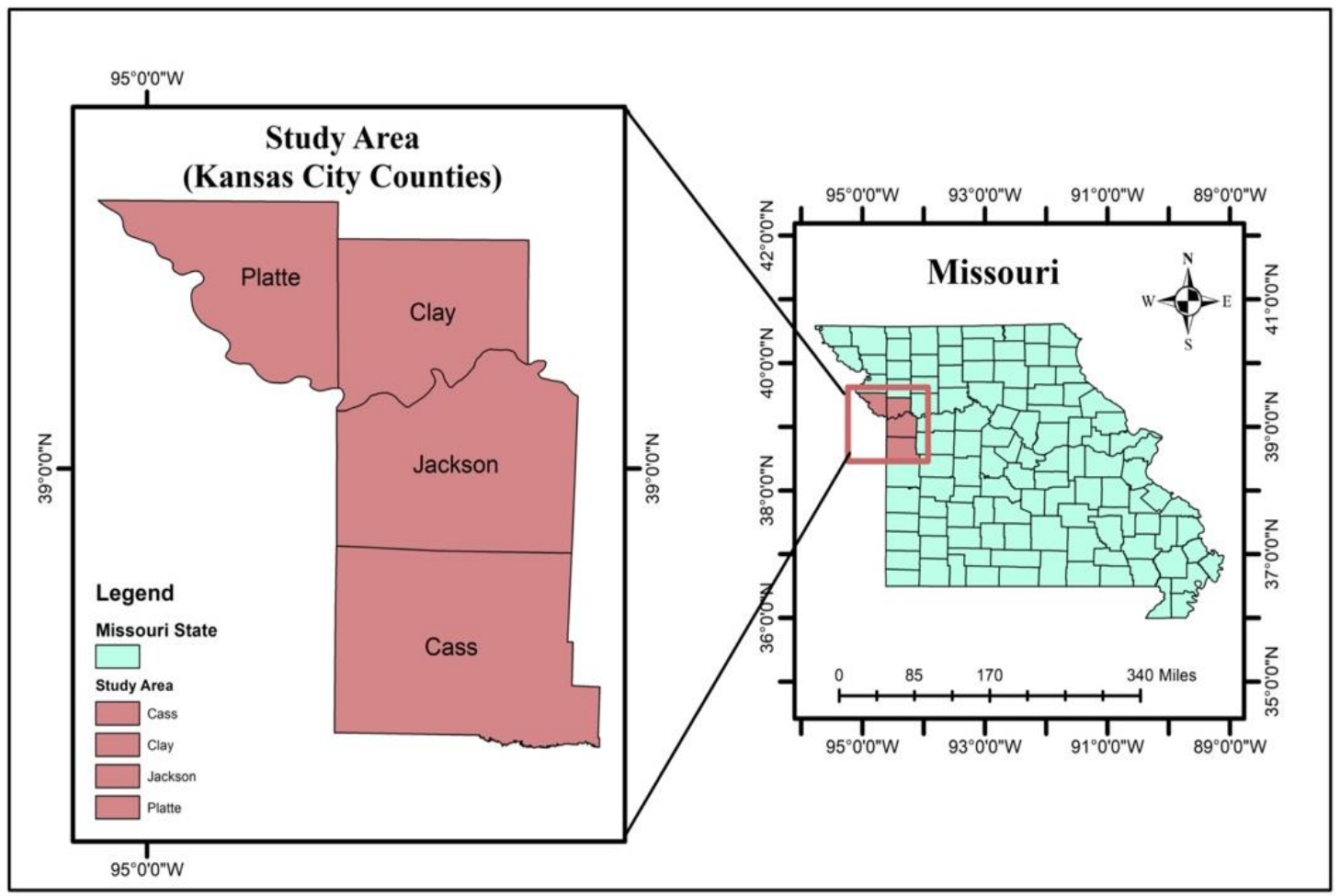

Figure 1. Missouri State map (right), Kansas City counties map (left).

We collaborated with the KCMO Health Department to obtain the necessary data for this study. KCMO Health Department provided the daily confirmed cases of COVID-19 between March 
2020 and February 2021. This study was approved by the KCMO Health Department, has been granted a waiver of informed consent, and is compliant with the Health Insurance Portability and Accountability Act.

Table 1 provides the basic descriptive statistics of Kansas City, MO, weekly COVID-19 data, and the weekly COVID-19 cases and deaths until February 2021, as represented in Figure 2(a).

Table 1: Descriptive statistics of Kansas City, MO weekly COVID-19 data from March 2020 to February 2021.

\begin{tabular}{lccc}
\hline & $\begin{array}{c}\text { \# of affected zip } \\
\text { codes }\end{array}$ & confirmed cases & mortality \\
\hline Minimum & $10(0,3,7)$ & $13(0,6,7)$ & $0(0,0,0)$ \\
\hline Maximum & $45(5,10,31)$ & $1899(216,617,1021)$ & $24(10,10,17)$ \\
\hline Mean & $36.9(3.8,8.2,25.0)$ & $712.9(71.3,201.4,415.2)$ & $9.1(1.2,2.3,5.3)$ \\
\hline Median & $39(4,8,26.5)$ & $616(59,136.5,383)$ & $6(0,1,3.5)$ \\
\hline STD & $7.1(1.0,1.5,5.1)$ & $555.9(65.6,184.7,294.6)$ & $7.4(1.9,2.6,5.0)$ \\
\hline Range & $35(5,7,24)$ & $1886(216,611,1014)$ & $24(10,10,17)$ \\
\hline
\end{tabular}

Note. The numbers inside the parentheses correspond to Platte, Clay, and Jackson counties, respectively. Of 48 zip codes in Kansas City, MO, there are 5, 11 and 32 zip codes in Platte, Clay, and Jackson counties, respectively.

\subsection{Space-Time Method}

To detect active or emerging space-time clusters, we utilized the prospective space-time scan statistic of the discrete Poisson model implemented in SaTScan software developed by (Kulldorf, 1997). Namely, we detected space-time COVID-19 clusters in Kansas City that were active and emerging at the end of the study period and ignored the non-statistically significant clusters that may have existed previously but are no longer a public health threat. We utilized the Poisson model because we were interested in the geographical distribution of COVID-19 cases in Kansas City between March 2020 and February 2021, adjusting for the population at risk.

The prospective statistic uses a cylinder window with a space base and height corresponding to the time. The center of the cylinder is defined as the centroid of each zip code in Kansas City, MO. The cylinder window is moved in two dominations: space and time. Hence, we obtained an infinite number of overlapping circles covering the entire study region, and each circle reflected a possible cluster of COVID-19 in the Kansas City area.

To avoid extremely large clusters, we set the upper maximum spatial scanning window size to $10 \%$ of the population at risk and the upper maximum temporal bound scanning window size to $50 \%$ of the study period. Each cylinder is expanded until the maximum spatial or temporal upper bound is reached. A likelihood ratio test was used to identify the space-time clusters of COVID19 cases (Kulldorff, 2001). The likelihood ratio is defined as follows: 


$$
\frac{L(C)}{L_{0}}=\frac{\left(\frac{n_{c}}{\mu(c)}\right)^{n_{c}}\left(\frac{N-n_{c}}{N-\mu(c)}\right)^{N-n_{c}}}{\left(\frac{N}{\mu(T)}\right)^{N}}
$$

The likelihood ratio is calculated based on the observed and expected number of cases inside and outside that circle, where $L(C)$ is the maximum likelihood function for cylinder $\mathrm{C}, L_{0}$ is the likelihood function under the null hypothesis, $n_{c}$ is the number of COVID-19 cases in a cylinder, $\mu(c)$ is the number of expected cases in cylinder c, $N$ is the total number of all observed cases in Kansas City over time, and $\mu(T)$ is the total number of expected cases in Kansas City over time. The likelihood was calculated for each cylinder to determine whether the observed number of cases exceeded the expected number of cases (i.e., the likelihood ratio is greater than 1). The window with the maximum likelihood ratio statistic constitutes the likeliest cluster (primary cluster). Secondary clusters are also reported if they are statistically significant at the $p$-value $<\alpha$ $=.05$.

The results section discusses the statistically significant emerging clusters of COVID-19 in Kansas City at the zip code level in four periods of three months: March-May 2020, MarchAugust 2020, March-November 2020, and March, 2020-February 2021. The spatial-temporal clusters were analyzed using SaTScan ${ }^{\mathrm{TM}}$ 9.6, and the maps were plotted using ArcGIS 10.8.

\section{Results}

\subsection{Time Series of COVID-19 Cases}

We used the time series of COVID-19 cases between March 2020 and February 2021. A total of 1,256 cases were eliminated from the data (see Figure 2(b)). These cases consisted of 1,215 cases from zip codes that did not belong to Kansas City, MO, and 41 cases that were labeled "unknown" in the data (for more details, such as the population of each county based on the zip codes, see Tables S1-S4 in the supplementary document).

Figure 2(a) shows the weekly COVID new cases and mortalities in Kansas City, MO. The total number of cases between March 2020 and February 2021 was 35,647, where 648 cases occurred before reopening (May 5, 2020), and the rest (17,273) after reopening. After the new COVID-19 restrictions, new weekly cases were stable at first before decreasing continuously. The time series of the cases (shown with a red curve) has multiple M-shaped (double-top) curves. There is a small "double top" from the $12^{\text {th }}$ week to the $20^{\text {th }}$ week with the maximum values in $15^{\text {th }}$ and $18^{\text {th }}$ week, and the minimum in $16^{\text {th }}$ week. There are also several "double tops" with larger magnitudes. One from the $27^{\text {th }}$ week to the $37^{\text {th }}$ week, another from the $37^{\text {th }}$ week to the $43^{\text {rd }}$ week, a third from the $43^{\text {rd }}$ week to the $48^{\text {th }}$ week, and a fourth from the $48^{\text {th }}$ week to the $55^{\text {th }}$ week. Figure 2(b) shows the graph of weekly cases per thousand for Clay County, Platte County, and Jackson County. Before the $16^{\text {th }}$ week, all counties had similar trends of cases per thousand, but Jackson County had more cases per thousand than Clay County and Platte County. Between the $22^{\text {nd }}$ and $37^{\text {th }}$ weeks, Jackson County had more cases per thousand. Between the $39^{\text {th }}$ and $40^{\text {th }}$ weeks, Platte County had more cases per thousand. From the $41^{\text {st }}$ week to the $47^{\text {th }}$ week, all counties had the same trend of cases per thousand, but Platte County had fewer cases per 
thousand than Clay County and Jackson County. From the $47^{\text {th }}$ week to the $49^{\text {th }}$ week and from the $51^{\text {st }}$ week to the $54^{\text {th }}$ week, Clay County had more cases per thousand. After the $54^{\text {th }}$ week, cases per thousand of all counties decreased continuously.

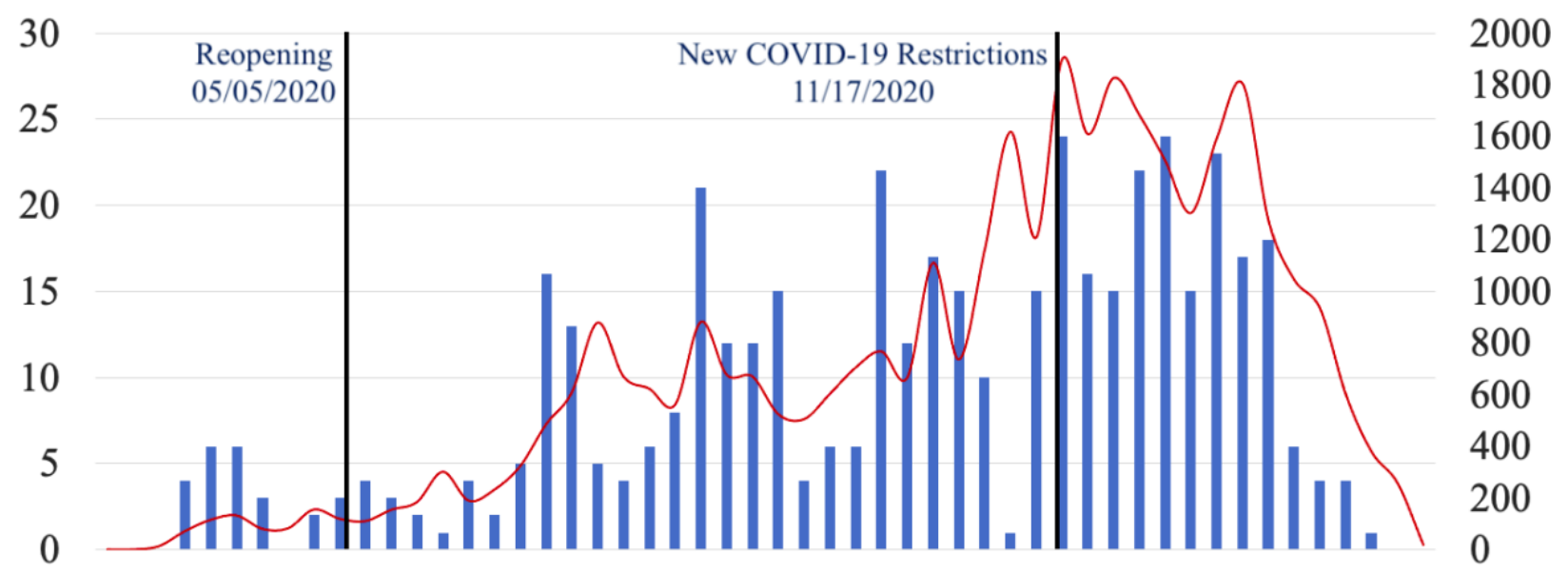

1012141618202224262830323436384042444648505254565860

(a)

-Weekly Death -Weekly New Case

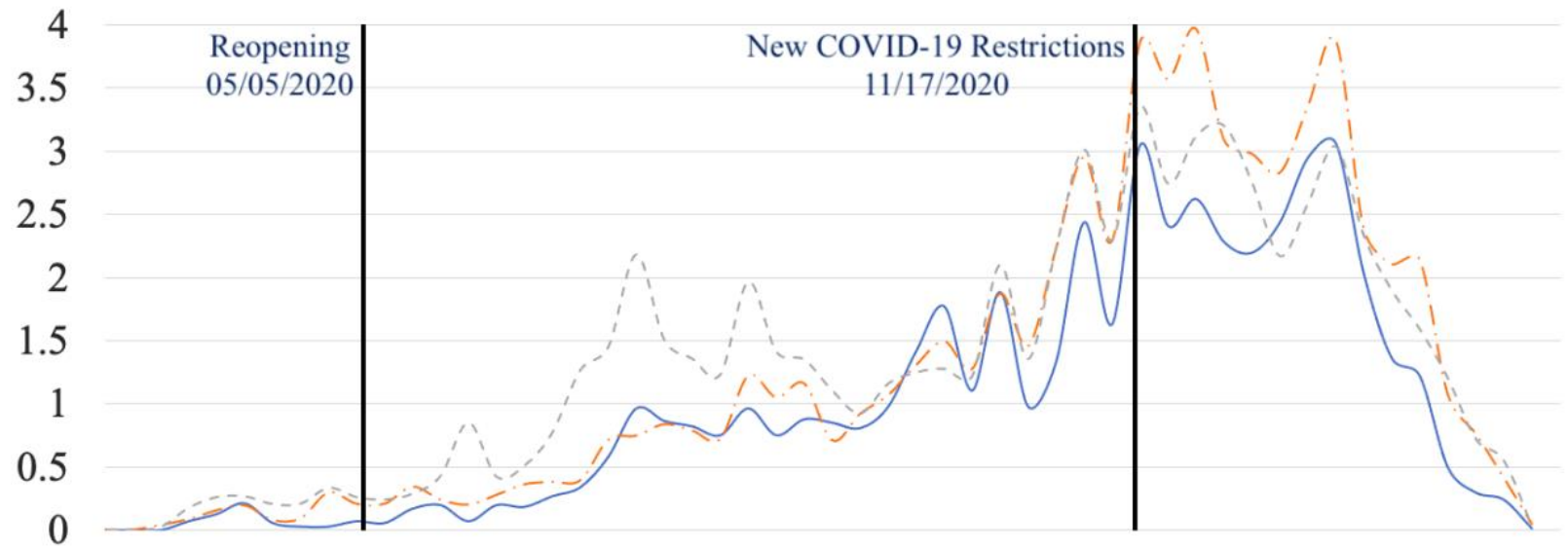

101214161820222426283032343638404244464850525456586062 (b) -Platte County - Clay County --Jackson County

Figure 2. Time series of COVID-19 cases in Kansas City, MO, between March 2020 and February 2021. (a) Number of new weekly cases and mortality, (b) number of new weekly cases per thousand by county. The vertical lines indicate the dates of reopening and applying the new COVID-19 restrictions.

\subsection{Space-time clusters of COVID-19 from periods 1 to 4}

Figure 3(a) presents the characteristics of the three statistically significant emerging space-time clusters of COVID-19 in Kansas City at the zip code level from March to May 2020. During period 1 , three statistically significant clusters emerged, which were mainly concentrated in downtown Kansas City, MO. Cluster 1 is located in northeast Kansas City and includes seven locations in Jackson County, with an RR of 9.21 (expected cases $=37.24$; observed cases $=274$ ). 
Cluster 2 contains two locations in Clay County, where the RR is 5.16, and there are 93 observed cases. Cluster 3 contains locations in downtown Kansas City, MO, with three locations in Jackson County, where the RR is 2.25 , and there are 42 observed cases.

Figure 3(b) shows the characteristics of the seven statistically significant emerging space-time clusters of COVID-19 in Kansas City at the zip code level from March to August 2020. By adding updated data of COVID-19 in Kansas City, four more clusters have emerged. The likeliest cluster (primary cluster) contains eight locations in Jackson County with $\mathrm{RR}=5.09$. Cluster 2 is located in downtown Kansas City, MO, with six locations in Jackson County and RR $=3.33$. Cluster 3 is found in south Kansas City and includes six locations in Jackson County with $\mathrm{RR}=3.24$. Cluster 4 contains nine locations in Clay County and two locations in Platte County with $\mathrm{RR}=2.76$. Cluster 5 contains eight locations in Jackson County with $\mathrm{RR}=1.71$. Clusters 6 and 7 contain only one location, each with $R R=1.99$ and 1.50 in Platte County and Clay County, respectively. We notice the clusters are spreading over a wider region in downtown and north of Kansas City. Also, cluster 2 in period 1 disappeared during period 2.

Figure 3(c) shows the characteristics and spatial patterns of the third period at the zip code level from March to November 2020. During this period, there were nine statistically significant emerging space-time clusters of COVID-19 that covered large areas of north and downtown Kansas City. All clusters during period 2 were still active in period 3. Note that cluster 2, which disappeared during period 2, reappeared during period 3 as cluster 5. Also, cluster 4 during period 2 became the primary cluster during period 3.

The likeliest cluster (primary cluster) contains nine locations in Clay County and two locations in Platte County with RR $=3.17$. Cluster 2 is located in downtown Kansas City, MO, with eight locations in Jackson County and $\mathrm{RR}=2.67$. Cluster 3 is found in south Kansas City and includes six locations in Jackson County with $\mathrm{RR}=2.13$. Cluster 4 contains three locations in Jackson with $\mathrm{RR}=2.07$. Cluster 5 contains four locations in Clay County with RR $=1.51$. Cluster 6 and 9 in Jackson County contain one location each with $\mathrm{RR}=3.88$ and 2.16, respectively. Clusters 7 and 8 contain one location each, with $\mathrm{RR}=1.58$ and 1.49 in Platte County and Clay County, respectively. During period 4, all of the clusters in period 3 were still active. Ten clusters were present, and most of the active clusters were along the state line.

Figure 3(d) shows the locations and spatial patterns of 10 emerging space-time clusters of COVID-19 in Kansas City, MO, between March 2020 and February 2021. The primary cluster contains nine locations in Clay County and two locations in Platte County with RR $=3.18$. Cluster 2 is located in downtown Kansas City, MO, with eight locations in Jackson County and $\mathrm{RR}=2.19$. Cluster 3 is a new cluster that emerged in this period, containing three locations with $\mathrm{RR}=1.95$ in Jackson County. Cluster 4 contains four locations in Clay County and one location in Jackson County with $R R=2.23$. Cluster 5 contains four locations in Jackson County with RR $=1.93$. Cluster 6 contains five locations in Jackson County and one location in Cass County with $\mathrm{RR}=1.87$. Clusters 7-9 contain one location each, with $\mathrm{RR}=2.34,4.83$, and 1.51 in Platte County, Jackson County, and Clay County, respectively. Cluster 10 contains three locations in Jackson County, with RR = 1.22. 

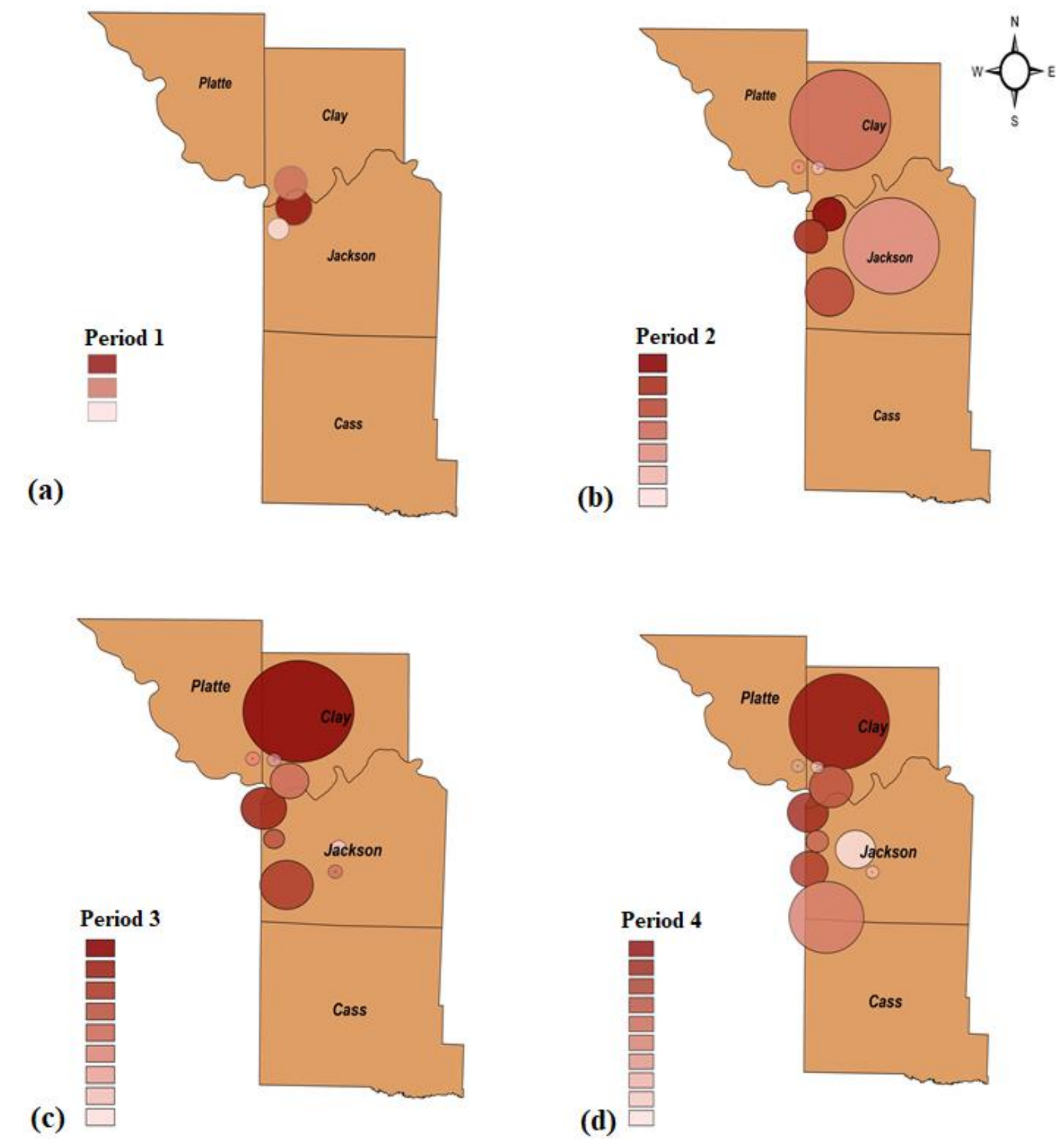

Figure 3. The emergence of COVID-19 clusters in Kansas City during four periods of three months: (a) Period 1: March-May 2020, downtown Kansas City, MO; (b) Period 2: MarchAugust 2020, additional clusters in the north and south; (c) Period 3: March-November 2020, further spread of clusters; and (d) Period 4: March, 2020-February 2021, active clusters along the state line. 
Table 2: Tracking the number of emerging clusters during the four periods of March- May 2020, with 3 active clusters, March-August 2020 increased to 7 clusters, March-November 2020 with 9 active clusters and the last period March,2020-February 2021 reaching to 10 active clusters. The relative risk (RR) and radius indicate the magnitude of each cluster.

\begin{tabular}{|c|c|c|c|c|c|c|c|c|c|c|c|}
\hline Period 1 & & & Period 2 & & & Period & & & Period & & \\
\hline $\begin{array}{l}\text { Cluster } \\
\#\end{array}$ & RR & Radius & $\begin{array}{l}\text { Cluster } \\
\#\end{array}$ & $\mathrm{RR}$ & Radius & $\begin{array}{l}\text { Cluster } \\
\#\end{array}$ & RR & Radius & $\begin{array}{l}\text { Cluster } \\
\text { \# }\end{array}$ & RR & Radius \\
\hline 1 & 9.21 & $\begin{array}{l}14 \\
\text { KM }\end{array}$ & 1 & 5.09 & 13.25 & 2 & 2.67 & $\begin{array}{l}16.55 \\
\mathrm{KM}\end{array}$ & 2 & 2.19 & $\begin{array}{l}16.55 \\
\mathrm{KM}\end{array}$ \\
\hline 2 & 5.16 & $\begin{array}{l}12.56 \\
\mathrm{KM}\end{array}$ & Disappeared & - & 0 & 5 & 1.51 & $\begin{array}{l}13.94 \\
\text { KM }\end{array}$ & 4 & 2.23 & $\begin{array}{c}17.49 \\
\text { KM }\end{array}$ \\
\hline 3 & 2.25 & $\begin{array}{l}8.10 \\
\text { KM }\end{array}$ & 2 & 3.33 & $\begin{array}{l}13.28 \\
\mathrm{KM}\end{array}$ & 4 & 2.07 & $\begin{array}{l}7.54 \\
\text { KM }\end{array}$ & 5 & 1.93 & $\begin{array}{l}9.11 \\
\text { KM }\end{array}$ \\
\hline - & - & - & 3 & 3.24 & $\begin{array}{l}19.34 \\
\mathrm{KM}\end{array}$ & 3 & 2.13 & $\begin{array}{l}19.34 \\
\text { KM }\end{array}$ & 6 & 1.87 & $\begin{array}{l}30.21 \\
\mathrm{KM}\end{array}$ \\
\hline - & - & - & 4 & 2.76 & $\begin{array}{l}40.16 \\
\mathrm{KM}\end{array}$ & 1 & 3.17 & $\begin{array}{l}40.16 \\
\text { KM }\end{array}$ & 1 & 3.18 & $\begin{array}{c}40.16 \\
\text { KM }\end{array}$ \\
\hline - & - & - & 5 & 1.71 & $\begin{array}{l}38.34 \\
\mathrm{KM}\end{array}$ & 6 & $\begin{array}{r}3.88 \\
2.16\end{array}$ & $\begin{array}{l}10.11 \\
\mathrm{KM} \\
10.11 \\
\mathrm{KM}\end{array}$ & $\begin{array}{l}8 \\
10\end{array}$ & $\begin{array}{l}4.83 \\
1.22\end{array}$ & $\begin{array}{l}10.11 \\
\mathrm{KM} \\
16.11 \\
\mathrm{KM}\end{array}$ \\
\hline - & - & - & 6 & 1.99 & $\begin{array}{l}15.17 \\
\mathrm{KM}\end{array}$ & 7 & 1.58 & $\begin{array}{l}15.17 \\
\text { KM }\end{array}$ & 7 & 2.34 & $\begin{array}{l}15.6 \\
\mathrm{KM}\end{array}$ \\
\hline - & - & - & 7 & 1.50 & $\begin{array}{l}15.17 \\
\mathrm{KM}\end{array}$ & 8 & 1.49 & $\begin{array}{l}15.17 \\
\mathrm{KM}\end{array}$ & 9 & 1.51 & $\begin{array}{l}15.17 \\
\mathrm{KM}\end{array}$ \\
\hline - & - & - & - & - & - & - & - & - & 3 & 1.95 & 15.17 \\
\hline
\end{tabular}

By adding updated COVID-19 data, we identify emerging clusters, which allows us to track the previously detected clusters to determine whether they are growing or shrinking. Table 2 summarizes the cluster changes during the four periods, starting with three clusters and ending with 10 clusters at the end of February 2021. For instance, the primary cluster during period 1 and $\mathrm{RR}=9.21$ shrinks during period 2 with $\mathrm{RR}=5.09$, then grows as cluster 2 during periods 3 and 4 with $R R=2.67$ and 2.19, respectively. Also, cluster 2 with $R R=5.16$ during period 1 disappears in period 2 and reappears with growing magnitude as cluster 5 in period 3 and cluster 4 in period 4 with $R R=1.51$ and 2.23, respectively. In addition, cluster 4 during period 2 with $\mathrm{RR}=2.76$ becomes the primary cluster during periods 3 and 4 with $\mathrm{RR}=3.17$ and 3.18 , respectively. Lastly, cluster 5 during period 2, with $R R=1.71$, was split into clusters 6 and 9 during period 3 , with $R R=3.88$ and 2.16 , respectively. 


\section{Discussion}

In this paper, we utilized a prospective space-time analysis to detect emerging clusters of COVID-19 in Kansas City, MO, at the zip code level, providing results at four distinct periods. The prospective scanning statistic is a useful surveillance technique for tracking disease outbreaks after they have been exposed. It is critical to undertake fast statistical analysis to augment basic case and illness rate maps in order to better identify the highest-risk locations of COVID-19 and predict how risk will develop and alter over the course of the pandemic. The prospective strategy used in this study was useful for Kansas City's Health Department to track the outbreaks in Kansas City, MO in a timely manner.

The main point of the prospective approach is the ability to add updated COVID-19 data to identify emerging clusters, which enables us to track the previously detected clusters to determine if they are growing or shrinking. Rapid detection can help determine whether current measurement techniques are effective during the spread of COVID-19 in Kansas City. We present our results by utilizing the prospective approach for four periods: March-May 2020; March-August 2020; March-November 2020; and March 2020-February 2021. The updated results in Section 3.2 showcase the evolution of the COVID-19 outbreaks in Kansas City. Table 2 shows how the emerged clusters change over the time. For instance, cluster 2 during period 1 disappeared in period 2, but it showed up again with growing magnitude during period 3 as cluster 5 and in period 4 as cluster 4 , with respective RRs of 1.51 and 2.23. This observation will help decision makers to implement more control measures to avoid the rise of small outbreaks. In addition, when adding the updated cases to the prospective scan statistic, cluster 4 during period 2 with RR $=2.76$ becomes the primary cluster during periods 3 and 4 with $\mathrm{RR}=3.17,3.18$, respectively. Moreover, cluster 5 during period 2 with $R R=1.71$ was split into clusters 6 and 9 with respective RRs of 3.88 and 2.16 .

Periodic monitoring of outbreaks can be used for surveillance during an ongoing epidemic, which can help determine whether the current measurement techniques are effective at mitigating the spread of COVID-19 in Kansas City. For instance, Figure. 3d shows most of the hot spots of COVID-19 during period 4 in Kansas City, MO, where most of the active clusters occurred near the state line.

With the availability of updated data and the capabilities of space-time perspective analysis, we can evaluate existing tactics for limiting the spread of COVID-19 variations and forecast the future growth of the hardest-hit areas. 


\section{Acknowledgments}

We would like to thank KCMO Health Department for providing detailed necessary data for this study. Next, we thank UMKC Women's Council for the Graduate Assistance Funds (GAF) support

\section{Data statement}

The data that support the findings of this study are available on request from KCMO Health Department. The data are not publicly available due to their containing information that could compromise the privacy of research participants. 


\section{References}

Azage M, Kumie A, Worku A Bagtzoglou AC. Childhood diarrhea exhibits spatiotemporal variation in Northwest Ethiopia: A SaTScan spatial statistical analysis. PLoS One 2015;9.

Centers of Disease Control and Prevention. Basic of COVID-19. 2021a.

https://www.cdc.gov/coronavirus/2019-ncov/your-health/about-covid-19/basics-covid-19.html

Centers of Disease Control and Prevention. How COVID-19 Spreads.

https://www.cdc.gov/coronavirus/2019-ncov/prevent-getting-sick/how-covid-spreads.html, $2021 b$.

Centers of Disease Control and Prevention. Basics of COVID-19. 2021c.

https://www.cdc.gov/coronavirus/2019-ncov/your-health/about-covid-19/basics-covid-19.html

Centers of Disease Control and Prevention. Symptoms of COVID-19. 2021d.

https://www.cdc.gov/coronavirus/2019-ncov/symptoms-testing/symptoms.html

Centers of Disease Control and Prevention. COVID data tracker. 2021e.

https://covid.cdc.gov/covid-data-tracker/\#datatracker-home

Centers of Disease Control and Prevention. Reporting trends in number of COVID-19

vaccinations. 2021f.

https://www.cdc.gov/coronavirus/2019-ncov/vaccines/reporting-trends.html

Centers of Disease Control and Prevention. What you need to know about COVID-19 variants. $2021 \mathrm{~g}$.

https://www.cdc.gov/coronavirus/2019-ncov/variants/variant.html

Coleman M, Coleman M, Mabuza AM, Kok G, Coetzee M, Durrheim DN. Using the SaTScan method to detect local malaria clusters for guiding malaria control programmes. Malar $\mathbf{J}$ 2009;8:68. https://doi.org/10.1186/1475-2875-8-68.

Desjardins MR, Hohl A, Delmelle EM. Rapid surveillance of COVID-19 in the United States using a prospective space-time scan statistic: Detecting and evaluating emerging clusters. Appl Geogr 2020;118:102202. https://doi.org/10.1016/j.apgeog.2020.102202.

Edens C, Alden NB, Danila RN, Fill M-MA, Gacek P, Muse A, et al. Multistate analysis of prospective Legionnaires' disease cluster detection using SaTScan, 2011-2015. PLoS One 2019; 14:e0217632.

Gao P, Guo D, Liao K, Webb JJ, Cutter SL. Early Detection of Terrorism Outbreaks Using Prospective Space-Time Scan Statistics. Prof Geogr 2013;65:676-91.

https://doi.org/10.1080/00330124.2012.724348.

Groshen EL. COVID-19's impact on the U.S. labor market as of September 2020. Bus Econ 
2020:1-16. https://doi.org/10.1057/s11369-020-00193-1.

James E. Kansas City, Missouri, makes list of cities named possible COVID-19 hot spots. https://www.kshb.com/news/coronavirus/kansas-city-missouri-makes-list-of-cities-namedpossible-covid-19-hot-spots, (2020).

Kansas City COVID-19 Information Center. COVID-19. https://kcmo.maps.arcgis.com/apps/dashboards/a9cb1fa166aa44de99dab0b946b08799, (2021).

Kansas City Health Department. KCMO Coronavirus Activity Timeline. 2021a. https://www.kcmo.gov/city-hall/departments/health/coronavirus-covid-19/coronavirus-covid-192/kcmo-coronavirus-activity-timeline

Kansas City Health Department. Kansas City COVID-19 Information Center. 2021b. https://www.kcmo.gov/city-hall/departments/health/coronavirus-covid-19/covid-19-totals

Kulldorff M. Prospective time periodic geographical disease surveillance using a scan statistic. J R Stat Soc Ser A (Statistics Soc 2001;164:61-72. https://doi.org/https://doi.org/10.1111/1467985X.00186.

Kulldorff M. A spatial scan statistic. Commun Stat - Theory Methods 1997;26:1481-96. https://doi.org/10.1080/03610929708831995.

Kulldorff M, Feuer EJ, Miller BA, Freedma LS. Breast cancer clusters in the Northeast United States: A geographic analysis. Am J Epidemiol 1997;146:161-70. https://doi.org/10.1093/oxfordjournals.aje.a009247.

Kulldorff M, Nagarwalla N. Spatial disease clusters: Detection and inference. Stat Med 1995;14:799-810. https://doi.org/https://doi.org/10.1002/sim.4780140809.

Melvin SC, Wiggins C, Burse N, Thompson E MM. The role of public health in COVID-19 emergency response efforts from a rural health perspective. Prev Chronic Dis 2020. https://doi.org/http://dx.doi.org/10.5888/pcd17.200256.

Missouri's Covid-19 Dashboard. COVID-19 Vaccination in Missouri 2021. https://covidvaccine.mo.gov/data/, (2021)

Shi Y, Wang G, Cai X, Deng J, Zheng L, Zhu H, et al. An overview of COVID-19. J Zhejiang Univ B 2020;21:343-60. https://doi.org/10.1631/jzus.B2000083.

Takahashi K, Kulldorff M, Tango T, Yih K. A flexibly shaped space-time scan statistic for disease outbreak detection and monitoring. Int J Health Geogr 2008;7:14. https://doi.org/10.1186/1476-072X-7-14.

UC Davis Health. Delta variant: 8 things you should know about this COVID-19 strain. https://health.ucdavis.edu/coronavirus/covid-19-information/delta-variant.html, (2021). 
The World Bank. Food Security and COVID-19.

https://www.worldbank.org/en/topic/agriculture/brief/food-security-and-covid-19, (2021)

World Health Organization. Rolling updates on coronavirus disease (COVID-19). 2020a. https://www.who.int/emergencies/diseases/novel-coronavirus-2019/events-as-they-happen

World Health Organization. Impact of COVID-19 on people's livelihoods, their health and our food systems. 2020b.

https://www.who.int/news/item/13-10-2020-impact-of-covid-19-on-people's-livelihoods-theirhealth-and-our-food-systems

Xu B, Madden M, Stallknecht DE, Hodler TW, Parker KC. Spatial and spatial-temporal clustering analysis of hemorrhagic disease in white-tailed deer in the southeastern USA: 19802003. Prev Vet Med 2012;106:339-47. https://doi.org/10.1016/j.prevetmed.2012.04.001.

Yale Medicine. Comparing the COVID-19 vaccines: How are they different? 2021a. https://www.yalemedicine.org/news/covid-19-vaccine-comparison

Yale Medicine. 5 things to know about the Delta variant 2021b.

https://www.yalemedicine.org/news/5-things-to-know-delta-variant-covid 


\section{Supplementary Documents}

\section{Space-time clusters of COVID-19 from periods 1 to 4}

Table S1: Emerging space-time clusters of COVID-19 March-May 2020 (Period 1) at the zip code level

\begin{tabular}{llllllll}
\hline Cluster & $\begin{array}{l}\text { Duration } \\
\text { (Month) }\end{array}$ & RR* & Observed & Expected & Counties & $\begin{array}{l}\text { \# of } \\
\text { locations }\end{array}$ & $\begin{array}{l}\boldsymbol{P} \text { - } \\
\text { value }\end{array}$ \\
\hline $\begin{array}{l}\text { Cluster 1 } \\
\text { (Primary) }\end{array}$ & May & 9.21 & 274 & 37.24 & $\begin{array}{l}\text { Jackson } \\
\text { County }\end{array}$ & 7 & $1 * 10^{-17}$ \\
\hline Cluster 2 & May & 5.16 & 93 & 19.20 & Clay County & 2 & $1 * 10^{-17}$ \\
\hline Cluster 3 & May & 2.25 & 42 & 19.06 & $\begin{array}{l}\text { Jackson } \\
\text { County }\end{array}$ & 3 & $\begin{array}{l}2.4^{*} 10^{-} \\
4\end{array}$ \\
& & & & & & &
\end{tabular}

Table S2: Emerging space time clusters of COVID-19 March-August 2020 (Period 2) at the zip code level

\begin{tabular}{|c|c|c|c|c|c|c|c|}
\hline Cluster & $\begin{array}{l}\text { Duration } \\
\text { (Month) }\end{array}$ & $\mathbf{R} \mathbf{R}^{*}$ & Observed & Expected & Counties & $\begin{array}{l}\text { \# of } \\
\text { locations }\end{array}$ & $\begin{array}{l}P \text { - } \\
\text { value }\end{array}$ \\
\hline $\begin{array}{l}\text { Cluster } 1 \\
\text { (Primary) }\end{array}$ & June-Aug & 5.09 & 1717 & 403.71 & $\begin{array}{l}\text { Jackson } \\
\text { County }\end{array}$ & 8 & $1 * 10^{-17}$ \\
\hline Cluster 2 & July-Aug & 3.33 & 802 & 258.17 & $\begin{array}{l}\text { Jackson } \\
\text { County }\end{array}$ & 6 & $1 * 10^{-17}$ \\
\hline Cluster 3 & July-Aug & 3.24 & 825 & 273.68 & $\begin{array}{l}\text { Jackson } \\
\text { County }\end{array}$ & 6 & $1 * 10^{-17}$ \\
\hline Cluster 4 & July-Aug & 2.76 & 694 & 265.27 & $\begin{array}{l}\text { Clay County } \\
\text { Platte } \\
\text { County }\end{array}$ & 11 & $1 * 10^{-17}$ \\
\hline Cluster 5 & July-Aug & 1.71 & 367 & 218.11 & $\begin{array}{l}\text { Jackson } \\
\text { County }\end{array}$ & 8 & $1 * 10^{-17}$ \\
\hline Cluster 6 & July-Aug & 1.99 & 214 & 108.71 & $\begin{array}{l}\text { Platte } \\
\text { County }\end{array}$ & 1 & $1 * 10^{-17}$ \\
\hline Cluster 7 & Aug & 1.50 & 135 & 90.52 & Clay County & 1 & $\begin{array}{l}1.4^{*} 10^{-} \\
3\end{array}$ \\
\hline
\end{tabular}


Table S3: Emerging space time clusters of COVID-19 March-November 2020 (Period 3) at the zip code level

\begin{tabular}{|c|c|c|c|c|c|c|c|}
\hline Cluster & $\begin{array}{l}\text { Duration } \\
\text { (Month) }\end{array}$ & $\mathbf{R} \mathbf{R}^{*}$ & Observed & Expected & Counties & $\begin{array}{l}\text { \# of } \\
\text { locations }\end{array}$ & $\begin{array}{l}P \text { - } \\
\text { value }\end{array}$ \\
\hline $\begin{array}{l}\text { Cluster } 1 \\
\text { (Primary) }\end{array}$ & Aug-Nov & 3.17 & 2135 & 735.21 & $\begin{array}{l}\text { Clay County } \\
\text { Platte County }\end{array}$ & 11 & $1 * 10^{-17}$ \\
\hline Cluster 2 & Aug-Nov & 2.67 & 1808 & 724.52 & $\begin{array}{l}\text { Jackson } \\
\text { County }\end{array}$ & 8 & $1 * 10^{-17}$ \\
\hline Cluster 3 & Aug-Nov & 2.13 & 1541 & 758.52 & $\begin{array}{l}\text { Jackson } \\
\text { County }\end{array}$ & 6 & $1 * 10^{-17}$ \\
\hline Cluster 4 & Aug-Nov & 2.07 & 1098 & 548.78 & $\begin{array}{l}\text { Jackson } \\
\text { County }\end{array}$ & 3 & $1 * 10^{-17}$ \\
\hline Cluster 5 & Aug-Nov & 1.51 & 1053 & 712.18 & Clay County & 4 & $1 * 10^{-17}$ \\
\hline Cluster 6 & Aug-Nov & 3.88 & 85 & 22.00 & $\begin{array}{l}\text { Jackson } \\
\text { County }\end{array}$ & 1 & $1 * 10^{-17}$ \\
\hline Cluster 7 & Aug-Nov & 1.58 & 472 & 301.30 & Platte County & 1 & $\begin{array}{l}1.3 * 10^{-} \\
15\end{array}$ \\
\hline Cluster 8 & Oct-Nov & 1.49 & 371 & 250.88 & Clay County & 1 & $\begin{array}{l}3.4^{*} 10^{-} \\
9\end{array}$ \\
\hline Cluster 9 & Aug-Nov & 2.16 & 58 & 26.88 & $\begin{array}{l}\text { Jackson } \\
\text { County }\end{array}$ & 1 & $\begin{array}{l}1.4^{*} 10^{-} \\
-\end{array}$ \\
\hline
\end{tabular}


Table S4: Emerging space time clusters of COVID-19 March-February 2020 (Period 4) at the zip code level

\begin{tabular}{|c|c|c|c|c|c|c|c|}
\hline Cluster & $\begin{array}{l}\text { Duration } \\
\text { (Month) }\end{array}$ & $\mathbf{R R}^{*}$ & Observed & Expected & Counties & $\begin{array}{l}\text { \# of } \\
\text { locations }\end{array}$ & $\begin{array}{l}P \text { - } \\
\text { value }\end{array}$ \\
\hline $\begin{array}{l}\text { Cluster } 1 \\
\text { (Primary) }\end{array}$ & $\begin{array}{l}\text { Sept } 20-\text { Feb } \\
21\end{array}$ & 3.18 & 4258 & 1475.55 & $\begin{array}{l}\text { Clay County } \\
\text { Platte } \\
\text { County }\end{array}$ & 11 & $1 * 10^{-17}$ \\
\hline Cluster 2 & $\begin{array}{l}\text { Sept } 20-\text { Feb } \\
21\end{array}$ & 2.19 & 3020 & 1454.10 & $\begin{array}{l}\text { Jackson } \\
\text { County }\end{array}$ & 8 & $1 * 10^{-17}$ \\
\hline Cluster 3 & $\begin{array}{l}\text { Oct 20-Feb } \\
21\end{array}$ & 1.95 & 2295 & 1221.43 & $\begin{array}{l}\text { Jackson } \\
\text { County }\end{array}$ & 3 & $1 * 10^{-17}$ \\
\hline Cluster 4 & $\begin{array}{l}\text { Dec 20-Feb } \\
21\end{array}$ & 2.23 & 1551 & 715.20 & $\begin{array}{l}\text { Clay County } \\
\text { Jackson } \\
\text { County }\end{array}$ & 5 & $1 * 10^{-17}$ \\
\hline Cluster 5 & $\begin{array}{l}\text { Oct } 20-\mathrm{Feb} \\
21\end{array}$ & 1.93 & 2160 & 1155.63 & $\begin{array}{l}\text { Jackson } \\
\text { County }\end{array}$ & 4 & $1 * 10^{-17}$ \\
\hline Cluster 6 & $\begin{array}{l}\text { Oct } 20-\mathrm{Feb} \\
21\end{array}$ & 1.87 & 1541 & 844.57 & $\begin{array}{l}\text { Jackson } \\
\text { County } \\
\text { Cass County }\end{array}$ & 6 & $1 * 10^{-17}$ \\
\hline Cluster 7 & $\begin{array}{l}\text { Dec 20-Feb } \\
21\end{array}$ & 2.34 & 694 & 300.68 & $\begin{array}{l}\text { Platte } \\
\text { County }\end{array}$ & 1 & $1 * 10^{-17}$ \\
\hline Cluster 8 & $\begin{array}{l}\text { Oct } 20-\mathrm{Feb} \\
21\end{array}$ & 4.83 & 177 & 36.83 & $\begin{array}{l}\text { Jackson } \\
\text { County }\end{array}$ & 1 & $1 * 10^{-17}$ \\
\hline Cluster 9 & $\begin{array}{l}\text { Dec 20-Feb } \\
21\end{array}$ & 1.51 & 748 & 500.73 & Clay County & 1 & $1 * 10^{-17}$ \\
\hline Cluster 10 & $\begin{array}{l}\text { Dec 20-Feb } \\
21\end{array}$ & 1.22 & 929 & 762.81 & $\begin{array}{l}\text { Jackson } \\
\text { County }\end{array}$ & 3 & $\begin{array}{l}1.9 * 10^{-} \\
6\end{array}$ \\
\hline
\end{tabular}

